\title{
Rancang Bangun Layanan Cloud Computing Berbasis IaaS Menggunakan Virtualbox
}

\author{
Muhammad Faizal Afriansyah, Adian Fatchur Rochim, Eko Didik Widianto \\ Jurusan Teknik Sistem Komputer, Fakultas Teknik, Universitas Diponegoro, \\ Jln. Prof. Sudharto, Tembalang, Semarang, Indonesia \\ email : muhammadfaizalafriansyah@gmail.com
}

\begin{abstract}
Today, the growth of technology is very fast and a lot of technology that can facilitate users in helping their activity is made. A technology need a server to store both systems and users data. More users needed more servers to store user data. The server room became full and needed the extra space so that it required high cost to build the server and the server space itself.

The purpose of this research is to create an IaaS based server virtualization that is connected to a router, switch, virtual client and administrator with VirtualBox application. The purpose of this research can be achieved by designing an appropriate research's methodology.

There are 5 stages of implementation/methodology in building virtualization server at this research which are the system definition, requirements specification, system configuration, system testing, and system analysis. First, phase of the definition system is by describing a system of early identification, system requirements and network topology on the implemented system. The second phase is the specification requirements to determine specifications hardware and software. The hardware consists of a computer with resources 8GB RAM and AMD Phenom II X6 as a processor. The software consists of VirtualBox and operating systems. The third stage is the system configuration to declare the source code in application on each server, routers and switches to perform the function of each device. The final stage is system testing and system analysis by checking the system is ready to use and works the best.

Results in this research show IaaS-based server virtualization can be connected to display a web page on all clients through virtual switches and routers on a computer.
\end{abstract}

Key Terms: Cloud computing, internet, networks, IaaS, VirtualBox.

\section{PEndahuluan}

$\mathrm{T}$ EKNOLOGI informasi saat ini semakin canggih dan terus berkembang di berbagai aspek kehidupan, internet sudah menjadi kebutuhan sangat penting pada masyarakat daerah perkotaan. Internet memudahkan pengguna untuk mengakses dan bertukar informasi dengan cepat dan mudah. Seluruh informasi dan data disimpan pada sebuah server. Server harus mempunyai kapasitas memori yang besar sehingga dapat menampung banyak data dan informasi. Semakin banyaknya informasi dan data yang masuk mengakibatkan diperlukannya banyak server. Server yang banyak akan memakan biaya dan ruang. Tidak hanya server, perangkat keras lainnya seperti switch dan router banyak memerlukan ruang dan biaya yang tidak sedikit. Berdasarkan masalah yang telah dijelaskan, solusi yang tepat dalam penerapan teknologi dalam efisiensi biaya dan ruang dengan menggunakan teknologi virtualisasi. Konsep virtualisasi server merupakan paradigma baru dalam perkembangan teknologi. Hal ini disebabkan virtualisasi memungkinkan penggunaan satu perangkat keras untuk menjalankan beberapa sistem operasi atau services pada saat yang sama, sehingga client dapat menggunakan sumber daya tersebut sesuai dengan kebutuhannya berbasis internet.

Teknologi virtualisasi hadir untuk membangun sebuah infrastruktur teknologi informasi ke tingkat yang lebih tinggi tanpa harus dihadapkan pada biaya investasi yang lebih tinggi. Hal ini sangat penting karena seiring pertumbuhan teknologi yang sangat pesat, maka infrastruktur teknologi informasi juga ditingkatkan kualitasnya. Tujuan teknologi virtualisasi adalah untk menghindari pemborosan daya proses yang mahal atau dengan kata lain meningkatkan efisiensi serta mengoptimalkan penggunaan prosessor berinti lebih dari satu. Penghematan lain adalah biaya listrik karena hanya menggunakan satu atau sedikit server saja.

Banyak sekali terdapat metode perancangan virtualisasi server dengan tipe cluster high availibility, antara lain menggunakan Proxmox, VMware ESX, OpenStack dan VirtualBox yang merupakan tipe virtualisasi server opensource dan mudah dalam melakukan instalasi. Terdapat perbedaan dalam hal kinerja diantara tipe virtualisasi server tersebut. Hal ini dikarenakan tipe virtualisasi server tersebut dibuat oleh vendor yang berbeda. ${ }^{[1]}$

Tugas akhir ini bertujuan untuk menghasilkan sebuah rancang bangun virtualisasi server berbasis IaaS yang terkoneksi dengan switch dan router disertai klien secara virtual dan admin dengan aplikasi VirtualBox yang optimal dan efisien pada sebuah komputer. Sistem virtualisasi berbasis IaaS diharapkan juga sebagai bahan pembelajaran mahasiswa untuk mengenal tentang virtualisasi jaringan.

\section{TINJAUAN PUSTAKA}

\section{A. Cloud Computing}

Cloud computing merupakan sebuah model sumber daya komputasi seperti daya komputasi, penyimpanan, jaringan dan perangkat lunak yang disediakan sebagai layanan di internet. Kerja cloud computing adalah pengguna dapat mengakses file, data, program dan layanan pada Web browser melalui internet yang disediakan oleh ISP. Pengguna hanya membayar untuk sumber daya komputasi dan jasa yang digunakan. 


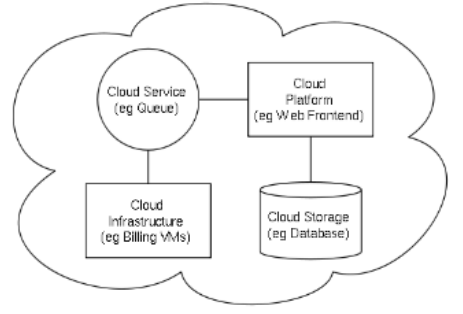

Gambar 1 Arsitektur cloud computing

Gambar 1 menjelaskan arsitektur cloud computing meliputi beberapa modul, yaitu cloud service, platform cloud, cloud infrastructure dan cloud storage. Cloud service merupakan sebuah layanan yang sangat diperlukan karena dapat mengefisienkan proses sehingga meningkatkan keuntungan bagi penggunanya. Cloud service terbagi menjadi cloud platform dan cloud infrastructure. Cloud platform biasanya berupa bahasa pemrograman seperti AJAX, PHP, atau Ruby on Rais. Cloud infrastructure merupakan komponen backbone cloud computing yang menyediakan semua fungsi, layanan, dan kemampuan penyimpanan untuk menyediakan data bagi pengguna. Cloud storage mempunyai relasi dengan cloud platform sebagai sebuah media penyimpanan file, data, program dan aplikasi. Cloud computing sering menggunakan teknik virtualisasi untuk mengalokasikan dan merealokasikan sumber daya komputasi secara dinamis. ${ }^{[12]}$

\section{B. IaaS}

IaaS (Infrastructure as a Service) adalah salah satu jenis model cloud computing yang menyediakan seluruh kebutuhan infrastruktur untuk di sewakan mulai penyimpanan, perangkat keras dan semua infrastruktur tersebut telah disediakan oleh provider cloud. Pengguna IaaS harus bertanggung jawab sepenuhnya untuk mengontrol infrastruktur yang disewakan. Pengguna IaaS akan bertanggung jawab untuk semua aspek keamanan sistem yang digunakan kecuali keamanan fisik yang akan ditangani oleh penyedia cloud. Konfigurasi sumber daya bisa diubah sesuai kebutuhan pengguna. Amazon, Rackspace, Xerox dan IBM adalah contoh penyedia IaaS. ${ }^{[8]}$

\section{Mesin Virtual}

Mesin virtual adalah sebuah implementasi perangkat lunak pada mesin komputer yang dapat menjalankan program yang sama seperti layaknya sebuah komputer aslinya. Mesin virtual (virtual machine) mirip dengan pendekatan terlapis dengan sedikit tambahan berupa antarmuka yang menghubungkan hardware dengan kernel untuk tiap-tiap proses. ${ }^{[5]}$

\section{Virtualisasi}

Virtualisasi diartikan sebagai pembuatan suatu bentuk atau versi virtual dengan sesuatu yang bersifat fisik, misalnya sistem operasi, perangkat penyimpanan data atau sumber daya jaringan. Dengan virtualisasi, maka sebuah komputer (fisik) bisa menjalankan banyak komputer virtual sekaligus pada saat yang bersamaan.

Virtualisasi memungkinkan adanya skalabilitas dan elastisitas yang tidak terjadi pada teknologi tradisional. Berdasarkan segi elastisitas, teknologi virtualisasi ini memberi keluasan pengguna layanan untuk dapat meningkatkan kapasitas layanan yang ingin dimilikinya. Berdasarkan segi skalabilitas, dengan virtualisasi ini nantinya pengguna dapat dengan mudah meningkatkan kinerja sistem secara berangsur-angsur sesuai dengan beban pekerjaan dengan hanya mengurangi ataupun menambahkan sejumlah prosesor secara virtual sesuai dengan kebutuhan. ${ }^{[2]}$

\section{E. Hypervisor}

Hypervisor atau lebih dikenal dengan istilah VMM (Virtual Machine Monitor) adalah sebuah platform virtualisasi yang dapat menjalankan beberapa sistem operasi pada sebuah mesin fisik secar bersamaan. Fungsi utama hypervisor adalah mengisolasi perangkat keras untuk masing-masing mesin virtual dan hypervisor juga berfungsi mengelola akses antara sistem operasi yang berjalan di atasnya dengan perangkat keras yang tersedia. Hypervisor diklasifikasikan menjadi dua jenis, yaitu:

1) Tipe 1 (native, bare metal)

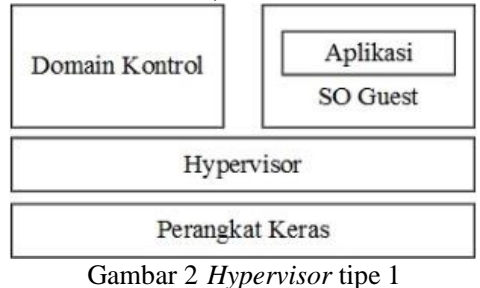

Gambar 2 menjelaskan hypervisor tipe 1 menggunakan perangkat lunak yang berjalan secara langsung pada perangkat keras host sebagai kontrol perangkat keras dan monitor sistem operasi guest. Sistem operasi guest berjalan pada tingkatan yang berbeda, yaitu di atas sistem hypervisor.

Contoh hypervisor yang menggunakan sistem ini adalah VMware ESX Server, LynxSecure dari LynuxWorks, L4 microkernels termasuk OKL4 dari Open Kernel Labs, Real Time System RTS-hypervisor, Wind River's hypervisor dan VxWorks Mils Platform, XtratuM.

2) Tipe 2 (host)

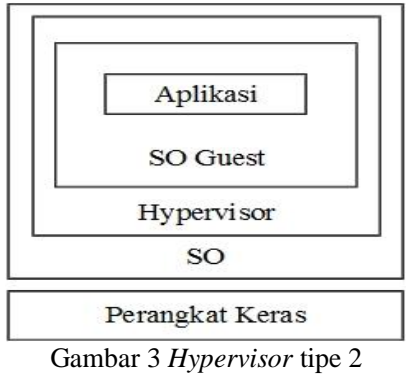

Gmbar 3 menjelaskan hypervisor tipe 2 menggunakan perangkat lunak yang berjalan dalam lingkup sistem operasi. Sistem operasi guest berjalan pada tingkatan ketiga di atas perangkat keras dalam sistem ini.

Contoh hypervisor yang menggunakan sistem ini adalah Vmware Server (sebelumnya dikenal sebagai GSX), Vmware Workstation, Vmware Fusion, open source QEMU, Microsoft Virtual PC, Sun (sebelumnya Innotek) Virtualbox, dan TenAsys' ${ }^{2}$ M. $^{[7]}$

\section{PERANCANGAN SISTEM}

\section{A. Definisi Sistem}

Definisi sistem akan topologi jaringan, arsitektur sistem dan cara kerja sistem yang akan digunakan untuk menentukan spesifikasi kebutuhan sistem pada tahap selanjutnya.

1) Topologi Jaringan

Sistem ini didesain terlebih dahulu menggunakan topologi jaringan. Topologi jaringan merupakan hal yang menjelaskan hubungan geometris antara unsur-unsur dasar penyusun jaringan, yaitu node, link, dan station. Topologi jaringan sistem ini dibuat dengan aplikasi Packet Tracer 6 yang disusun sesuai kebutuhan sistem yang akan dibuat. Berikut topologinya : 


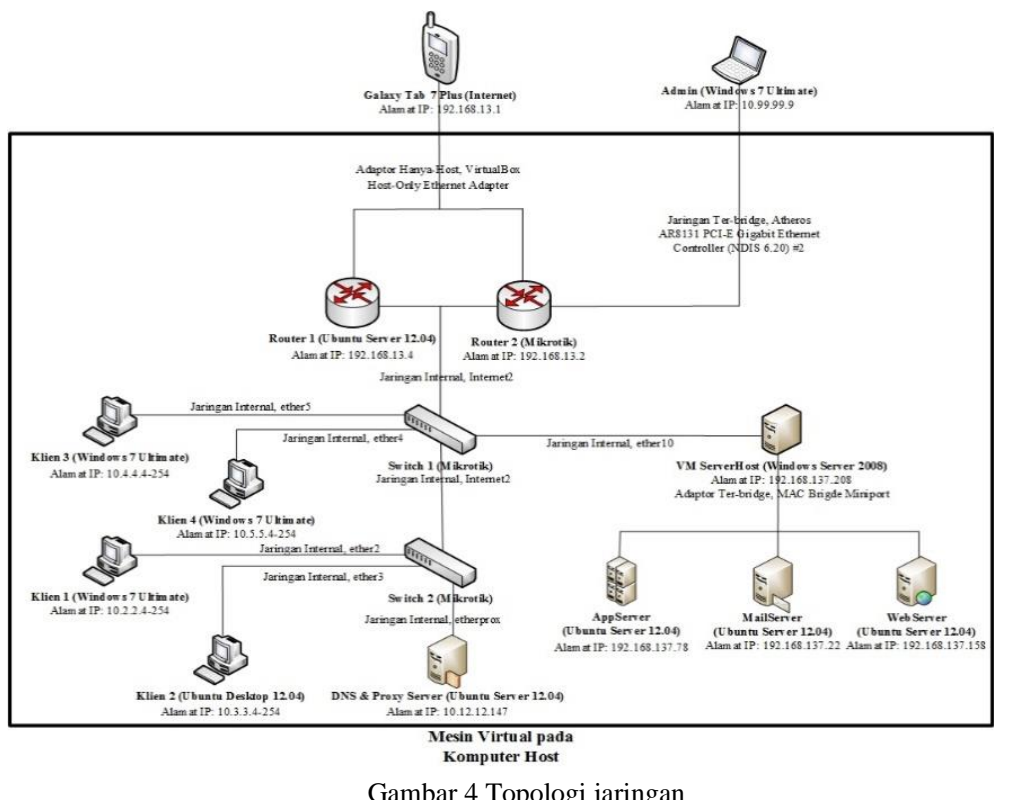

Berdasarkan topologi jaringan pada Gambar 4 menjelaskan terdapat 3 server yang memerlukan ruang yang besar dan memerlukan banyak resource seperti 2 router, 2 switch, 3 server, 1 ISP (Internet Service Provider), 1 laptop sebagai admin dan 4 buah komputer virtual sebagai klien. Topologi jaringan diatas juga menjelaskan bahwa klien terdiri atas beberapa VLAN yaitu VLAN2, VLAN3, VLAN4 dan VLAN5. Server pada virtualisasi ini juga terbagi menjadi 2 bagian yaitu Server Webserver dan proxy dan Server Host. Server Host pada topologi terdiri atas 3 server bagian, yaitu AppServer, MailServer dan WebServer.

Terdapat juga DNS Server dan Proxy server dalam virtualisasi ini. DNS Server adalah sebuah sistem yang mengubah nama host (seperti faizaweb.com) menjadi alamat IP (seperti 192.168.137.158) di atas semua komputer yang terhubung langsung ke Jaringan lokal. DNS juga dapat mengubah alamat IP menjadi nama host. DNS Server ini memanfaatkan aplikasi bind pada linux untuk mengolah IP menjadi nama tersebut. Proxy Server pada sistem ini berfungsi untuk memblok permintaan pada web dengan memunculkan sebuah peringatan. Aplikasi yang dipakai dalam proxy server ini adalah squid.

Switch pada topologi diatas berfungsi untuk menghubungkan seluruh VLAN yang telah diset ke 2 buah router dan 2 buah router ini mengarahkan jaringan lokal bisa mengakses ke ISP (Internet Service Provider). Terdapat pula jalur khusus yang dibuat hanya menuju admin. Admin dapat mengakses semua perangkat-perangkat yang terkoneksi.

2) Arsitektur Sistem

Arsitektur jaringan diperlukan agar informasi sistem yang dibuat dapat dengan mudah dipahami. Arsitektur jaringan yang digunakan dalam virtualisasi layanan cloud computing berbasis IaaS ini adalah arsitektur mesin virtual. Arsitektur ini terdiri atas perangkat keras, implementasi mesin virtual, nama mesin virtual atau ID mesin virtual dan proses.

Mesin virtual yang telah dibuat akan dimuat dengan sistem operasi sesuai kebutuhan. Sistem operasi yang digunakan sama seperti sistem operasi pada mesin fisik. Mesin virtual yang telah diinstal sistem operasi dapat menjalankan proses-proses komputasi seperti mesin fisik. Terdapat 2 arsitektur mesin virtual pada tugas akhir ini yaitu arsitektur pada komputer dan arsitektur pada Server Host.

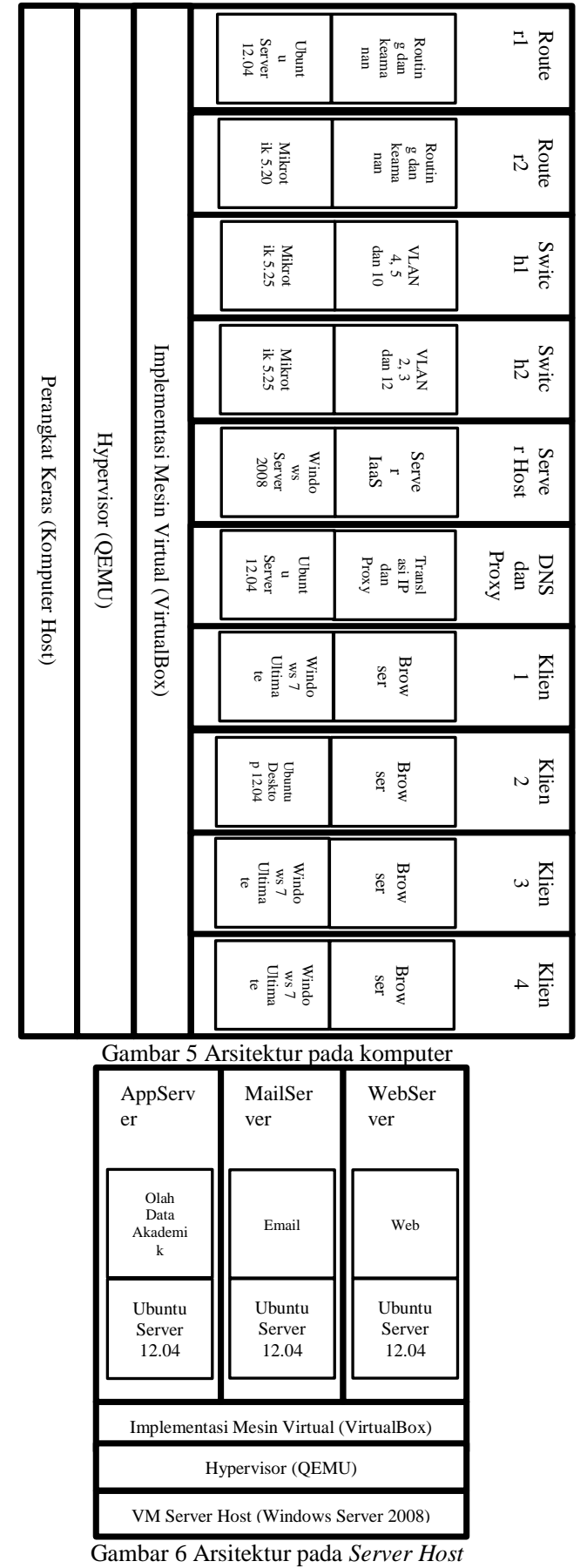

Gambar 5 menunjukkan arsitektur mesin virtual yang dibangun pada komputer. Arsitektur ini terdiri atas komputer sebagai perangkat keras, aplikasi VirtualBox sebagai implementasi mesin virtual, 10 mesin virtual, 6 sistem operasi dan proses pada masing masing mesin virtual. Mesin virtual yang digunakan pada arsitektur ini adalah Router 1, Router 2, Switch 1, Switch 2, DNS dan Proxy Server, Server Host, Klien 1, Klien 2, Klien 3, dan Klien 4. Sistem operasi yang digunakan pada arsitektur ini adalah Ubuntu Server 12.04, Windows Server 2008, Mikrotik, Windows 7, Ubuntu Desktop 12.04. Gambar 6 menunjukkan arsitektur mesin virtual yang dibangun pada mesin virtual Server Host dengan sistem operasi Windows Server 2008 yang telah dibuat sebelumnya. Arsitektur ini terdiri atas mesin virtual Server Host sebagai perangkat keras, aplikasi VirtualBox sebagai implementasi mesin virtual dari 3 mesin virtual , 1 sistem operasi dan proses pada masing masing mesin virtual. Mesin virtual yang digunakan pada arsitektur ini adalah MailServer, WebServer, dan AppServer. Sistem operasi yang digunakan pada arsitektur ini adalah Ubuntu Server 12.04. Penjabaran arsitektur sistem dari setiap mesin virtual dijelaskan pada Tabel 1.

Jurnal Teknologi dan Sistem Komputer, Vol.3, No.1, Januari 2015 (e-ISSN: 2338-0403)

JTsiskom - 89 
TABEL I

ARSITEKTUR SISTEM

\begin{tabular}{|c|c|c|c|}
\hline No. & $\begin{array}{l}\text { Nama Mesin } \\
\text { Virtual }\end{array}$ & $\begin{array}{l}\text { Sistem } \\
\text { Operasi }\end{array}$ & Proses \\
\hline 1 & Router 1 & $\begin{array}{l}\text { Ubuntu } \\
\text { Server } 12.04\end{array}$ & $\begin{array}{l}\text { Routing dan } \\
\text { keamanan }\end{array}$ \\
\hline 2 & Router 2 & Mikrotik 5.20 & $\begin{array}{l}\text { Routing dan } \\
\text { keamanan }\end{array}$ \\
\hline 3 & Switch 1 & Mikrotik 5.25 & $\begin{array}{l}\text { VLAN 4,5 } \\
\text { dan } 10\end{array}$ \\
\hline 4 & Switch 2 & Mikrotik 5.25 & $\begin{array}{l}\text { VLAN 2,3 } \\
\text { dan } 12\end{array}$ \\
\hline 5 & Server & $\begin{array}{l}\text { Windows } \\
\text { Server } 2008\end{array}$ & Server IaaS \\
\hline 6 & $\begin{array}{l}\text { DNS dan Proxy } \\
\text { Server }\end{array}$ & $\begin{array}{l}\text { Ubuntu } \\
\text { Server } 12.04\end{array}$ & $\begin{array}{l}\text { Translasi IP } \\
\text { dan Proxy }\end{array}$ \\
\hline 7 & WebServer & $\begin{array}{l}\text { Ubuntu } \\
\text { Server } 12.04\end{array}$ & Web \\
\hline 8 & AppServer & $\begin{array}{l}\text { Ubuntu } \\
\text { Server } 12.04\end{array}$ & $\begin{array}{l}\text { Olah Data } \\
\text { Akademik }\end{array}$ \\
\hline 9 & Mail Server & $\begin{array}{l}\text { Ubuntu } \\
\text { Server } 12.04\end{array}$ & Email \\
\hline 10 & Klien 1 & $\begin{array}{l}\text { Windows } 7 \\
\text { Ultimate }\end{array}$ & Browser \\
\hline 11 & Klien 2 & $\begin{array}{l}\text { Ubuntu } \\
\text { Dekstop } \\
12.04\end{array}$ & Browser \\
\hline 12 & Klien 3 & $\begin{array}{l}\text { Windows } 7 \\
\text { Ultimate }\end{array}$ & Browser \\
\hline 13 & Klien 4 & $\begin{array}{l}\text { Windows } 7 \\
\text { Ultimate }\end{array}$ & Browser \\
\hline
\end{tabular}

Hypervisor yang digunakan pada VirtualBox adalah $Q E M U$. Hypervisor ini berfungsi sebagai penghubung antara mesin virtual dan mesin fisik. VirtualBox berfungsi sebagai aplikasi pembuat mesin virtual. Mesin virtual dalam arsitektur dimaksudkan untuk menjalankan beberapa proses sekaligus yang terbagi dalam beberapa mesin virtual karena mesin fisik hanya dapat menjalankan satu proses saja. Mesin virtual dapat mengefisiensikan waktu pengerjaan, biaya dan ruang sebab kemudahan dan manfaat yang diberikan oleh mesin virtual.

3) Cara Kerja Sistem

Sistem virtualisasi cloud computing terdiri atas sever server yang tersedia. Server tersebut akan diakses oleh klien melalui jaringan lokal. Sistem ini merupakan virtualisasi sistem yang telah dibuat pada topologi jaringan. Cara kerja sistem cloud computing berbasis IaaS secara virtual ini akan dijelaskan pada Gambar 7.

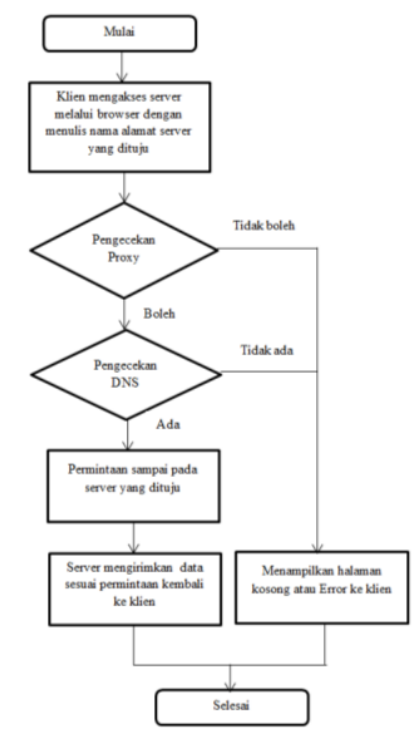

Gambar 7 Diagram alir cara kerja sistem

Berdasarkan Gambar 7 di atas, klien ingin mengakses sebuah web pada jaringan lokal maupun publik. Klien akan mengaksesnya melalui browser yang sudah tersedia pada masing masing komputer. Klien menulis nama alamat web yang akan dituju, kemudian komputer akan mengarahkan nama tersebut ke Proxy Server jika tidak akan menampilkan halaman kosong atau error. Proxy Server ini bertugas sebagai firewal untuk sumber alamat IP yang diijinkan lewat dan alamat web yang diijinkan lewat. Proxy server akan mengecek terlebih dahulu permintaan pada klien, jika permintaan itu tidak diblokir maka Proxy Server meneruskan permintaan langsung ke DNS (Domain Name Server). DNS bertugas sebagai penterjemah nama pada alamat web menjadi alamat IP (Internet Prootocol) sebagai alamat setiap komputer. Setelah menterjemahkan nama menjadi alamat IP, DNS akan mengecek permintaan tersebut, jika ada nama alamat yang dituju maka langsung meneruskan permintaan itu ke alamat IP yang dituju ke server yang mempunyai alamat IP yang sesuai dengan permintaan klien dan halaman web akan menampilkan pesan error jika diblokir. Server akan menerima permintaan tersebut dan memproses permintaan tersebut. Server akan mengirimkan data sesuai permintaan klien dan melalui jalur yang sama. Klien akan menerima data sesuai permintaan pada browser.

\section{B. Spesifikasi Requirement}

1) Spesifikasi Perangkat Keras
1. Prosessor
: AMD Phenom (tm)

II X6 1055T Processor (6CPUs), $\sim 2.8 \mathrm{GHz}$

2. RAM : 8192 MB RAM

3. VGA : ATI Radeon HD 5800

4. System Manufacture: MSI Series (4095 MB)

5. System Model : MS-7599

6. 1 buah Galaxy Tab 7 plus sebagai penyalur internet

7. 1 buah laptop axioo sebagai admin

2) Spesifikasi Perangkat Lunak

1. Sistem Operasi Windows 7 Ultimate 64 bit (komputer)

2. VirtualBox versi 4.3 .8 r92456

3. Windows Server 2008 r2

4. Ubuntu Server 12.04

5. Ubuntu 12.04 LTS

6. Mikrotik

7. Joomla versi 3.3.0

8. Roundcube

9. PHP 5

10. XAMPP/LAMPP

11. BIND

12. Squid

13. Winbox

14. Putty

15. PHPVirtualBox versi 4.3.1

16. DenyHosts

17. Port knocking

\section{Konfigurasi Sistem}

Setelah mengetahui bagaimana teori yang mendasari konsep suatu jaringan maka pada langkah selanjutnya adalah tahapan melakukan suatu konfigurasi sistem pada virtualisasi jaringan telah dibuat.

Hal yang terpenting dalam mengkonfigurasi sistem adalah menginstal terlebih dahulu aplikasi VirtualBox sebagai tempat dibuatnya mesin virtual pada virtualisasi jaringan ini. Tahap selanjutnya adalah menginstal sistem operasi pada 13 mesin virtual dan dilanjutkan mengkonfigurasi setiap mesin virtual sesuai fungsi dan tugas masing masing. 


\section{PENGUJIAN DAN ANALISIS}

\section{A. Pengujian Konektifitas}

Virtualisasi jaringan yang telah selesai ini akan dilakukan pengujian koneksi klien ke server dan klien terkoneksi DNS dan Proxy Server. Setiap perangkat memiliki sistem operasi yang akan menjalankan fungsi masing-masing perangkat dalam virtualisasi jaringan ini. Tabel 2 menjelaskan sistem operasi yang dipakai setiap perangkat.

TABEL II

INFORMASI PERANGKAT

\begin{tabular}{|c|c|c|c|c|c|c|}
\hline No. & $\begin{array}{l}\text { Nama Mesin } \\
\text { Virtual }\end{array}$ & $\begin{array}{l}\text { Sistem } \\
\text { Operasi }\end{array}$ & $\begin{array}{l}\text { Memori } \\
\text { RAM }\end{array}$ & Prosessor & $\begin{array}{l}\text { Media } \\
\text { Penyi } \\
\text { mpana } \\
\mathrm{n}\end{array}$ & $\begin{array}{l}\text { Vbox } \\
\text { ID/UUID }\end{array}$ \\
\hline 1 & Router 1 & $\begin{array}{l}\text { Ubuntu } \\
\text { Server } \\
12.04\end{array}$ & $512 \mathrm{MB}$ & $1 \mathrm{CPU}$ & $15 \mathrm{~GB}$ & $\begin{array}{l}\text { 5c6e173d- } \\
3 \mathrm{~b} 18-4 f 98- \\
955 \mathrm{e}- \\
\text { f4aab66e29 } \\
\text { b7 }\end{array}$ \\
\hline 2 & Router 2 & $\begin{array}{l}\text { Mikrotik } \\
5.20\end{array}$ & $256 \mathrm{MB}$ & $1 \mathrm{CPU}$ & $4 \mathrm{~GB}$ & $\begin{array}{l}801873 \mathrm{~d} 1- \\
\text { a3e6-423d- } \\
8778- \\
803731 \mathrm{~b} 65 \\
150\end{array}$ \\
\hline 3 & Switch 1 & $\begin{array}{l}\text { Mikrotik } \\
5.25\end{array}$ & $256 \mathrm{MB}$ & $1 \mathrm{CPU}$ & $2 \mathrm{~GB}$ & $\begin{array}{l}\text { f44db785- } \\
\text { a2d3-41e4- } \\
8753- \\
\text { e5cc0a2e6d } \\
79\end{array}$ \\
\hline 4 & Switch 2 & $\begin{array}{l}\text { Mikrotik } \\
5.25\end{array}$ & $256 \mathrm{MB}$ & $1 \mathrm{CPU}$ & 2 GB & $\begin{array}{l}\text { 1676df3b- } \\
5660-42 f 3- \\
\text { b77b- } \\
\text { b924d719ce } \\
04\end{array}$ \\
\hline 5 & Server & $\begin{array}{l}\text { Windows } \\
\text { Server } \\
2008\end{array}$ & $2512 \mathrm{MB}$ & $5 \mathrm{CPU}$ & $55 \mathrm{~GB}$ & $\begin{array}{l}\text { ee01319f- } \\
0037-42 a 3- \\
\text { bbc4- } \\
7 d 5 d 6877 a \\
4 b c\end{array}$ \\
\hline 6 & $\begin{array}{l}\text { DNS dan } \\
\text { Proxy Server }\end{array}$ & $\begin{array}{l}\text { Ubuntu } \\
\text { Server } \\
12.04\end{array}$ & $512 \mathrm{MB}$ & $1 \mathrm{CPU}$ & $15 \mathrm{~GB}$ & $\begin{array}{l}\text { eae2e398- } \\
7413-44 e 8- \\
\text { ac92- } \\
\text { e7a7fd8f46 } \\
5 c\end{array}$ \\
\hline 7 & WebServer & $\begin{array}{l}\text { Ubuntu } \\
\text { Server } \\
12.04\end{array}$ & $512 \mathrm{MB}$ & $1 \mathrm{CPU}$ & $10 \mathrm{~GB}$ & $\begin{array}{l}\text { fb12848e- } \\
0 c 7 e-4 b 57- \\
8 e 8 f- \\
53 \text { aacc013e } \\
\text { a9 }\end{array}$ \\
\hline 8 & AppServer & $\begin{array}{l}\text { Ubuntu } \\
\text { Server } \\
12.04\end{array}$ & $512 \mathrm{MB}$ & $1 \mathrm{CPU}$ & $25 \mathrm{~GB}$ & $\begin{array}{l}\text { 6e89fcba- } \\
\text { 1d79-426b- } \\
9576- \\
\text { e68551b9eb } \\
\text { e8 }\end{array}$ \\
\hline 9 & Mail Server & $\begin{array}{l}\text { Ubuntu } \\
\text { Server } \\
12.04\end{array}$ & $512 \mathrm{MB}$ & $1 \mathrm{CPU}$ & $25 \mathrm{~GB}$ & $\begin{array}{l}\text { 094fabbf- } \\
\text { a100-43a7- } \\
\text { b2bc- } \\
\text { 93faaf6098 } \\
\text { 3b }\end{array}$ \\
\hline 10 & Klien 1 & $\begin{array}{l}\text { Windows } \\
7 \\
\text { Ultimate }\end{array}$ & $512 \mathrm{MB}$ & $1 \mathrm{CPU}$ & 25 & $\begin{array}{l}\text { 72ee1158- } \\
6823-44 \mathrm{e} 0- \\
8 \mathrm{de} 1- \\
\text { be4d73ebd2 } \\
\text { eb }\end{array}$ \\
\hline 11 & Klien 2 & $\begin{array}{l}\text { Ubuntu } \\
\text { Dekstop } \\
12.04\end{array}$ & $512 \mathrm{MB}$ & $1 \mathrm{CPU}$ & $8 \mathrm{~GB}$ & $\begin{array}{l}816 f c 48 f- \\
\text { eef0-4012- } \\
91 \mathrm{~b} 3- \\
266 \mathrm{e} 98 \mathrm{f} 62 \mathrm{f} \\
4 \mathrm{f}\end{array}$ \\
\hline
\end{tabular}

\begin{tabular}{|c|c|c|c|c|c|c|}
\hline 12 & Klien 3 & $\begin{array}{l}\text { Windows } \\
7 \\
\text { Ultimate }\end{array}$ & $512 \mathrm{MB}$ & $1 \mathrm{CPU}$ & $25 \mathrm{~GB}$ & $\begin{array}{l}\text { 090c1376- } \\
\text { d464-48a3- } \\
9497- \\
2663764 a 0 \\
90 \mathrm{c}\end{array}$ \\
\hline 13 & Klien 4 & $\begin{array}{l}\text { Windows } \\
7 \\
\text { Ultimate }\end{array}$ & $512 \mathrm{MB}$ & $1 \mathrm{CPU}$ & $25 \mathrm{~GB}$ & $\begin{array}{l}\text { 7fd19113- } \\
8 \text { b7f-4df5- } \\
\text { a2f5- } \\
026 e 77662 \\
\text { d41 }\end{array}$ \\
\hline
\end{tabular}

Sebelum melakukan pengujian, harus adanya alamat IP untuk setiap perangkat atau mesin virtual untuk memudahkan pencarian perangkat tersebut. Tabel 3 menjabarkan semua alamat IP yang telah ditentukan pada virtualisasi ini.

TABEL III

INFORMASI ALAMAT IP

\begin{tabular}{|c|c|c|c|c|c|}
\hline No. & $\begin{array}{l}\text { Nama } \\
\text { Perangkat }\end{array}$ & Alamat IP & $\begin{array}{l}\text { Antarmuka pada } \\
\text { VirtualBox }\end{array}$ & Subnetmask & $\begin{array}{l}\text { Default } \\
\text { Gateway }\end{array}$ \\
\hline 1 & Router 1 & 192.168 .13 .4 & $\begin{array}{l}\text { Adaptor Hanya } \\
\text { Host, 'VirtualBox } \\
\text { Host-Only } \\
\text { Ethernet Adapter' }\end{array}$ & $\begin{array}{l}255.255 .255 . \\
0\end{array}$ & 192.168 .13 .1 \\
\hline 2 & Router 2 & 192.168.13.2 & $\begin{array}{l}\text { Adaptor Hanya } \\
\text { Host, 'VirtualBox } \\
\text { Host-Only } \\
\text { Ethernet Adapter' }\end{array}$ & $\begin{array}{l}255.255 .255 . \\
0\end{array}$ & 192.168 .13 .1 \\
\hline 3 & Switch 1 & 10.99 .99 .11 & $\begin{array}{l}\text { Jaringan Internal, } \\
\text { 'internet2' }\end{array}$ & $\begin{array}{l}255.255 .255 . \\
0\end{array}$ & 10.99 .99 .1 \\
\hline 4 & Switch 2 & 10.99 .99 .22 & $\begin{array}{l}\text { Jaringan Internal, } \\
\text { 'internet2' }\end{array}$ & $\begin{array}{l}255.255 .255 . \\
0\end{array}$ & 10.99 .99 .1 \\
\hline 5 & Server Host & $\begin{array}{l}192.168 .137 .20 \\
8\end{array}$ & $\begin{array}{l}\text { Jaringan Internal, } \\
\text { 'ether10' }\end{array}$ & $\begin{array}{l}255.255 .255 . \\
0\end{array}$ & $\begin{array}{l}192.168 .137 \\
1\end{array}$ \\
\hline 6 & $\begin{array}{l}\text { DNS dan } \\
\text { Proxy Server }\end{array}$ & 10.12 .12 .147 & $\begin{array}{l}\text { Jaringan Internal, } \\
\text { 'etherprox' }\end{array}$ & $\begin{array}{l}255.255 .255 . \\
0\end{array}$ & 10.12 .12 .1 \\
\hline 7 & WebServer & $\begin{array}{l}192.168 .137 .15 \\
8\end{array}$ & $\begin{array}{l}\text { Jaringan Internal, } \\
\text { 'ether 10' }\end{array}$ & $\begin{array}{l}255.255 .255 . \\
0\end{array}$ & $\begin{array}{l}192.168 .137 \\
1\end{array}$ \\
\hline 8 & AppServer & 192.168 .137 .78 & $\begin{array}{l}\text { Jaringan Internal, } \\
\text { 'ether10' }\end{array}$ & $\begin{array}{l}255.255 .255 . \\
0\end{array}$ & $\begin{array}{l}192.168 .137 \\
1\end{array}$ \\
\hline 9 & MailServer & 192.168 .137 .22 & $\begin{array}{l}\text { Jaringan Internal, } \\
\text { 'ether10' }\end{array}$ & $\begin{array}{l}255.255 .255 . \\
0\end{array}$ & $\begin{array}{l}192.168 .137 \\
1\end{array}$ \\
\hline 10 & Klien 1 & 10.2 .2 .252 & $\begin{array}{l}\text { Jaringan Internal, } \\
\text { 'ether2' }\end{array}$ & $\begin{array}{l}255.255 .255 . \\
0\end{array}$ & 10.2 .2 .1 \\
\hline 11 & Klien 2 & 10.3 .3 .253 & $\begin{array}{l}\text { Jaringan Internal, } \\
\text { 'ether3' }\end{array}$ & $\begin{array}{l}255.255 .255 . \\
0\end{array}$ & 10.3 .3 .1 \\
\hline 12 & Klien 3 & 10.4 .4 .254 & $\begin{array}{l}\text { Jaringan Internal, } \\
\text { 'ether4' }\end{array}$ & $\begin{array}{l}255.255 .255 . \\
0\end{array}$ & 10.4 .4 .1 \\
\hline 13 & Klien 4 & 10.5 .5 .254 & $\begin{array}{l}\text { Jaringan Internal, } \\
\text { 'ether5' }\end{array}$ & $\begin{array}{l}255.255 .255 . \\
0\end{array}$ & 10.5 .5 .1 \\
\hline 14 & Admin & 10.99 .99 .9 & $\begin{array}{l}\text { Adaptor Ter- } \\
\text { bridge, Atheros } \\
\text { AR8131 PCI-E } \\
\text { Gigabit Ethernet } \\
\text { Controller (NDIS } \\
6.20)\end{array}$ & $\begin{array}{l}255.255 .255 . \\
0\end{array}$ & 10.99 .99 .1 \\
\hline
\end{tabular}

Selain alamat IP, terdapat juga VLAN yang digunakan dalam virtualisasi jaringan ini. Tabel 4 menjabarkan semua VLAN yang digunakan pada virtualisasi ini.

TABEL IV

INFORMASI VLAN

\begin{tabular}{|l|l|l|l|l|l|}
\hline No. & Nama VLAN & $\begin{array}{l}\text { VLAN- } \\
\text { ID }\end{array}$ & Alamat IP & Subnetmask & $\begin{array}{l}\text { Default } \\
\text { Gateway }\end{array}$ \\
\hline 1 & Vlan2 & 2 & 10.2 .2 .0 & 255.255 .255 .0 & 10.2 .2 .1 \\
\hline 2 & Vlan3 & 3 & 10.3 .3 .0 & 255.255 .255 .0 & 10.3 .3 .1 \\
\hline 3 & Vlan4 & 4 & 10.4 .4 .0 & 255.255 .255 .0 & 10.4 .4 .1 \\
\hline 4 & Vlan5 & 5 & 10.5 .5 .0 & 255.255 .255 .0 & 10.5 .5 .1 \\
\hline 5 & Vlan10 & 10 & 192.168 .137 .0 & 255.255 .255 .0 & 192.168 .137 .1 \\
\hline 6 & Vlan12 & 12 & 10.12 .12 .0 & 255.255 .255 .0 & 10.12 .12 .1 \\
\hline 7 & VLANAdmin & 99 & 10.99 .99 .0 & 255.255 .255 .0 & 10.99 .99 .1 \\
\hline
\end{tabular}


1) Pengujian Konektifitas VLAN

Skenario pengujian konektifitas VLAN dilakukan untuk mengetahui VLAN yang telah dibuat berjalan dengan baik dan benar. Pengujian ini dilakukan dengan cara melakukan ping pada command prompt klien 1 sebagai sampel.

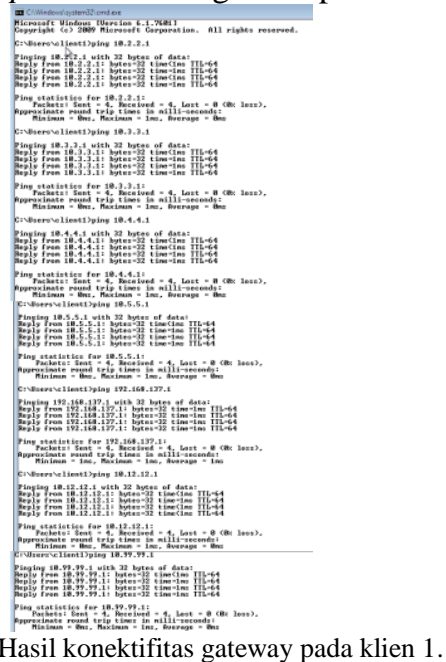

Gambar 8 Hasil konektifitas gateway pada klien 1

Gambar 8 menunjukkan bahwa VLAN yang telah dibuat dalam virtualisasi jaringan ini berhasil dengan baik tanpa ada packet loss. Packet loss adalah banyaknya paket yang hilang selama proses transmisi oleh sebuah node pengirim dan diterima di node tujuan. Packet loss biasanya diartikan dengan Request Time out pada command prompt.

2) Pengujian Konektifitas Server Host

Pengujian ini dilakukan untuk menguji Server Host sudah berjalan dengan baik dan menampilkan hasil sesuai keinginan. Pengujian Server Host dilakukan dengan pengujian sampel 1 klien untuk mengakses masing masing server pada Server Host. Pengujian pertama adalah menguji server MailServer dengan alamat mail.faizalmail.com.

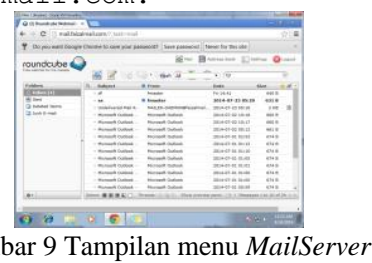

Gambar 9 menunjukkan user telah masuk ke dalam MailServer dan di dalam MailServer dapat mengirim pesan seperti pada MailServer biasanya. Pengujian selanjutnya adalah menguji konektifitas WebServer dengan alamat web faizalweb.com dan berikut hasil pengujian.

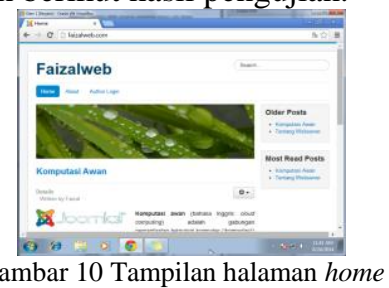

Gambar 10 merupakan tampilan WebServer dalam Server Host. WebServer ini juga terdapat halaman admin yang dapat dikonfigurasi secara bebas dan sesuai dengan keinginan. Pengujian terakhir adalah menguji konektifitas Appserver pada Server Host dengan alamat web sia.faizal.com dan berikut adalah hasil pengujiannya.

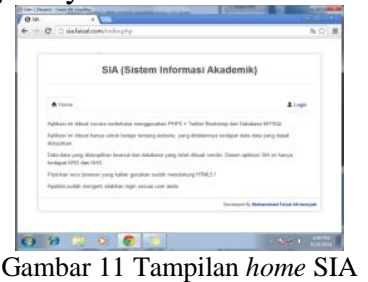

Gambar 11 menunjukkan tampilan web pada server AppServer. AppServer ini menampilkan program seperti SIA (Sistem Informasi Akademik) dalam bentuk yang sederhana. Terdapat menu login yang terbagi menjadi login sebagai admin dan mahasiswa.

3) Pengujian Pemblokiran Situs

Pengujian pemblokiran situs dilakukan untuk mengamati sistem sudah terpasang pemblokiran beberapa situs yang dianggap memberikan efek negatif kepada pengguna dan tidak bermanfaat. Pengujian dilakukan pada sisi klien dan sudah terhubung ke internet.

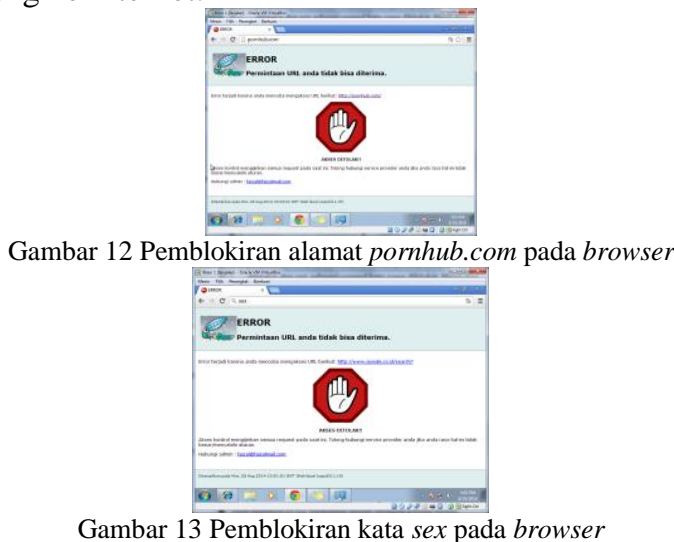

Berdasarkan gambar di atas, pengujian server proxy telah berhasil dengan baik dan sesuai keinginan. Gambar 12 menunjukkan hasil pemblokiran alamat web Proxy Server. Gambar 13 menunjukkan hasil pemblokiran kata sex yang dilakukan server Proxy.

\section{B. Pengujian Keamanan}

1) Pengujian Keamanan Router 1

Pengujian ini dilakukan untuk menguji performansi keamanan pada virtualisasi jaringan. Pengujian dilakukan di luar jaringan pada virtualisasi jaringan dan perangkat yang diuji adalah Router 1. Router 1 telah terpasang aplikasi DenyHosts yang berfungsi untuk memblokir alamat IP yang mencoba masuk kedalam sistem dengan menebak user dan password dengan 3 kali penebakan yang gagal.
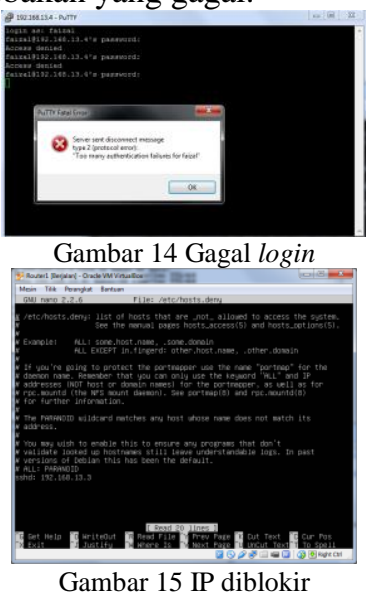

Gambar 14 menunjukkan input password yang gagal dengan 3 kali percobaan dan sistem akan langsung menolak koneksi hacker. Pada saat hacker dipaksa keluar sistem, maka sistem akan langsung membuat list alamat IP yang diblokir seperti yang ditunjukkan pada Gambar 15.

2) Pengujian Keamanan Router 2

Pengujian keamanan Router 2 berfungsi sama seperti Router 1 yaitu melindungi sistem pada serangan luar jaringan. Pengujian ini menggunakan metode Port knocking. Sistem akan menutup semua port dan satu cara untuk membuka port tersebut dengan mengetuk port-port yang tertutup tersebut sesuai urutan yang telah ditentukan oleh sistem dan IP tertentu.

Jurnal Teknologi dan Sistem Komputer, Vol.3, No.1, Januari 2015 (e-ISSN: 2338-0403)

JTsiskom - 92 


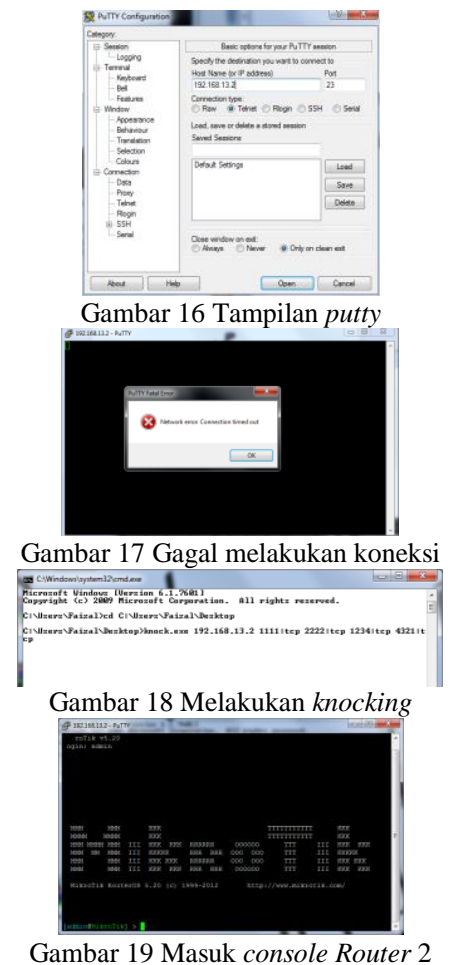

Gambar 19 menunjukkan IP 192.168.13.1 akan masuk ke sistem Router 2 dengan menggunakan putty melalui jalur telnet/port 23. Gambar 14 menunjukkan gagal masuk sistem karena port telnet ditutup. Gambar 15 menunjukkan bahwa untuk masuk ke dalam sistem harus menggunakan aplikasi knock.exe untuk mengetuk port-port yang tertutup tersebut. Konfigurasi yang dilakukan harus melalui cmd sebagai berikut: cd $C: \backslash$ Users $\backslash$ Faizal $\backslash$ Desktop //perintah ini untuk berpindah ke direktori lain yang menuju aplikasi knock. exe itu di simpan . knock.exe 192.168.13.2 1111:tcp 2222:tcp 1234:tcp 4321 : tcp //perintah ini untuk mengetuk port yang tertutup sesuai alamat yang dituju. Gambar 16 menunjukan hasil port telnet yang telah dibuka dan alamat IP 192.68.13.1 dapat masuk ke console Router 2.

\section{Analisis Sistem}

\section{1) Analisa Waktu Kinerja Sistem}

Analisa ini merupakan analisa yang didapat berdasarkan pengamatan terhadap waktu yang diperlukan pada saat mesin pertama dijalankan sampai siap digunakan dan pengamatan terhadap waktu yang diperlukan pada saat mematikan setiap perangkat. Waktu diambil dengan melakukan 3 kali percobaan dan dalam keadaan satu persatu dijalankan dan dimatikan.

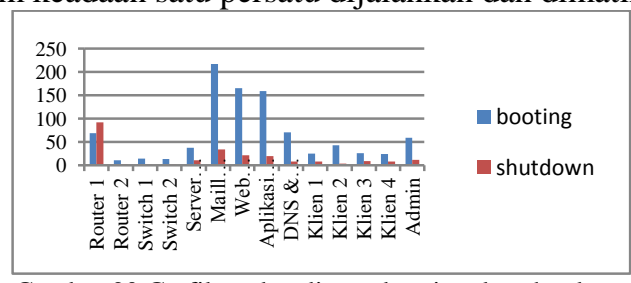

Gambar 20 Grafik perbandingan booting dan shutdown

Berdasarkan Gambar 20 menjelaskan waktu rata-rata yang diperlukan untuk menjalankan sebuah sistem operasi masingmasing perangkat. Waktu yang diperlukan Mikrotik untuk menjalankan mesin hanya sekitar 13 detik saja. Waktu terlama memerlukan waktu sampai 3 menit 37 detik pada sistem operasi Ubuntu Server 12.04 pada Router 1 begitu juga pada waktu yang diperlukan mikrotik untuk mematikan mesin hanya sekitar 1-2 detik saja. Waktu terlama memerlukan waktu sampai 1 menit 31 detik pada sistem operasi ubuntu server 12.04 pada Router 1 . Sistem operasi sangat berpengaruh besar dalam pengamatan ini, sistem operasi ubuntu lebih memerlukan waktu yang lebih dibandingkan dengan sistem operasi windgws ${ }_{\text {gurnal }}^{\text {dan }}$ sistem operasi mikrotik adalah yang tercepat daripada sistem operasi windows server 2008, ubuntu server 12.04, windows 7 ultimate dan ubuntu desktop 12.04.

2) Analisis Kinerja Server

Tahap analisa server dilakukan dengan mengambil kebutuhan memory sistem pada saat program MySQL dan Apache dijalankan dan pada saat program MySQL dan apche dimatikan serta waktu yang diperlukan MySQL dan Apache untuk dijalankan dan dimatikan. Analisa ini dilakukan pada 3 server cloud yaitu MailServer, WebServer, dan Appserver. MailServer menggunakan aplikasi Postfix dan Roundcube. WebServer menggunakan aplikasi Joomla dan AppServer menggunakan aplikasi PHP.

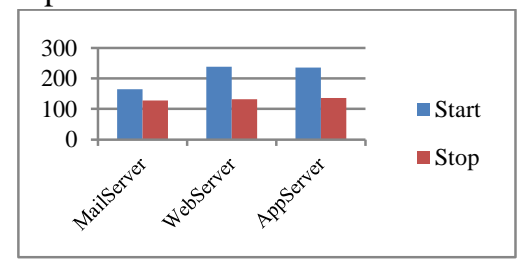

Gambar 21 Grafik perbandingan penggunaan memori

Berdasarkan pada Gambar 21 menjelaskan bahwa kebutuhan memory saat sebelum dan sesudah MySQL dan Apache dijalankan pada MailServer lebih kecil (sebesar $128 \mathrm{MB}$ dan $165 \mathrm{MB})$ dibandingkan kebutuhan memory pada WebServer (sebesar $132 \mathrm{MB}$ dan $239 \mathrm{MB}$ ) dan AppServer (sebesar $136 \mathrm{MB}$ dan $236 \mathrm{MB}$ ). Jadi dapat disimpulkan bahwa penggunaan aplikasi Postfix dan Roundcube berbanding terbalik juga dengan penggunaan aplikasi Joomla dan PHP pada kebutuhan memorinya.

3) Webtester dan Performansi Server

Tahap analisa webtester dan performansi server dilakukan dengan mengambil sebuah nilai perbandingan RAM sebelum dan sesudah klien mengakses masing-masing server. Terdapat simulasi klien yang digunakan dalam analisis ini. Klien akan mengakses setiap server dan akan dilihat perubahan nilai RAM pada server tersebut. Masing-masing server terdiri atas AppServer, WebServer, dan MailServer serta memiliki RAM sebesar 512 MB. Aplikasi yang digunakan dalam analisis ini adalah Apache Jmeter dan webalizer.

Analisis webtester dan performansi telah dilakukan dan didapatkan hasil penggunaan RAM dan prosessor maksimum pada masing-masing server. Tabel 5 menunjukkan RAM dan prosessor sebelum diakses oleh simulasi klien. Tabel 6 menunjukkan RAM dan prosessor setelah diakses oleh simulasi klien.

TABEL $V$

PENGGUNAAN RAM DAN PROSESSOR SEBELUM DIAKSES

\begin{tabular}{|l|l|c|c|}
\hline No. & Perangkat & RAM & Prosessor \\
\hline 1 & AppServer & $248102 \mathrm{kB}$ & $9,3 \%$ \\
\hline 2 & MailServer & $176444 \mathrm{kB}$ & $10,9 \%$ \\
\hline 3 & WebServer & $239532 \mathrm{kB}$ & $7,9 \%$ \\
\hline \multicolumn{4}{|c}{ TABEL VI } \\
\hline
\end{tabular}

PENGGUNAAN RAM DAN PROSESSOR SETELAH DIAKSES

\begin{tabular}{|l|l|c|c|}
\hline No. & Perangkat & RAM & Prosessor \\
\hline 1 & AppServer & $490680 \mathrm{kB}$ & $91,4 \%$ \\
\hline 2 & MailServer & $399587 \mathrm{kB}$ & $93,8 \%$ \\
\hline 3 & WebServer & $501472 \mathrm{kB}$ & $91,2 \%$ \\
\hline
\end{tabular}

Beradasarkan Tabel 5 didapatkan hasil penggunaan RAM dan prosessor sebelum diakses oleh simulasi klien. Penggunaan RAM terkecil sebelum diakses oleh simulasi klien adalah MailServer sebesar $176444 \mathrm{kB}$ dibandingkan dengan AppServer sebesar $248102 \mathrm{kB}$ dan WebServer sebesar $239532 \mathrm{kB}$. Penggunaan prosessor terkecil sebelum diakses oleh simulasi klien adalah WebServer sebesar 7,9 \% dibandingkan dengan 15 (e-ISSN: 2338-0403)
JTsiskom - 93 
AppServer sebesar 9,3 \% dan MailServer sebesar 10,9\%. Beradasarkan Tabel 6 didapatkan hasil penggunaan RAM dan prosessor setelah diakses oleh simulasi klien. Penggunaan RAM terkecil setelah diakses oleh simulasi klien adalah MailServer sebesar $399587 \mathrm{kB}$ dibandingkan dengan AppServer sebesar $490680 \mathrm{kB}$ dan WebServer sebesar 501472 kB. Penggunaan prosessor terkecil sebelum diakses oleh simulasi klien adalah WebServer sebesar 91,2 \% dibandingkan dengan AppServer sebesar 91,4\% dan MailServer sebesar 93,8\%. Berdasarkan Tabel 5 dan 6 dapat ditentukan penggunaan RAM dan prosessor maksimum pada masing-masing server yang ditunjukkan pada Tabel 7.

TABEL VII

PENGGUNAAN RAM DAN PROSESSOR MAKSIMUM

\begin{tabular}{|l|l|l|c|}
\hline No. & Server & $\begin{array}{l}\text { RAM } \\
\text { Maksimum }\end{array}$ & $\begin{array}{l}\text { Prosessor } \\
\text { Maksimum }\end{array}$ \\
\hline 1 & AppServer & $242578 \mathrm{kB}$ & $82,1 \%$ \\
\hline 2 & MailServer & $199935 \mathrm{kB}$ & $82,9 \%$ \\
\hline 3 & WebServer & $261940 \mathrm{kB}$ & $83,3 \%$ \\
\hline
\end{tabular}

Tabel 7 akan digambarkan menjadi grafik perbandingan. Grafik perbandingan bertujuan untuk menentukan perbedaan performansi pada masing-masing server. Grafik perbandingan pertama pada Gambar 22 menunjukkan penggunaan RAM maksimum pada masing-masing server. Grafik perbandingan kedua pada Gambar 23 menunjukkan penggunaan maksimum prosessor pada masing-masing server.

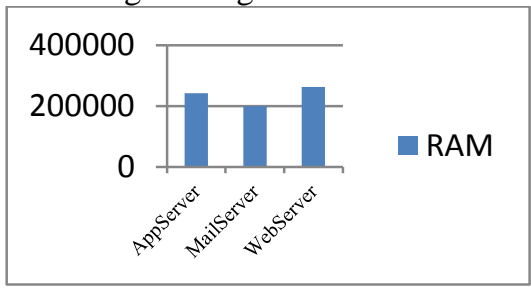

Gambar 22 Grafik perbandingan hasil penggunaan RAM maksimum.

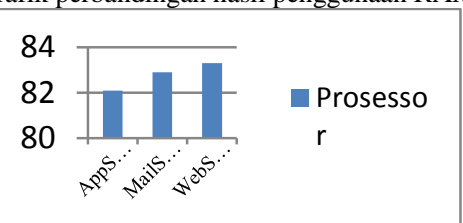

Gambar 23 Grafik perbandingan hasil penggunaan prosessor maksimum.

Berdasarkan Tabel 7 dan grafik perbandingan pada Gambar 22 dan 23 dapat disimpulkan bahwa WebServer adalah server dengan penggunaan RAM tertinggi dengan $261940 \mathrm{kB}$ dibanding AppServer dengan $242578 \mathrm{kB}$ dan MailServer dengan $199935 \mathrm{kB}$. Penggunaan prosessor tertinggi adalah WebServer dengan 83,3\% dibanding AppServer dengan 82,1\% dan MailServer dengan $82,9 \%$.

\section{KESIMPULAN DAN SARAN}

\section{A. Kesimpulan}

Berdasarkan hasil pengujian dan analisis pada BAB 4, dapat diambil beberapa kesimpulan sebagai berikut :

1 ) Rancang bangun cloud computing berbasis IaaS telah berhasil dibangun secara virtual dengan VirtualBox. Virtualisasi sistem dibangun dengan 13 mesin virtual, 5 sistem operasi dan setiap proses pada masing masing mesin virtual.

2 ) Setiap VLAN dapat saling berkomunikasi karena adanya konfigurasi routing pada router. Terdapat 7 VLAN yang digunakan dalam layanan cloud computing berbasis IaaS secara virtual.

3 ) Klien dapat mengakses mesin virtual dengan menggunakan RDP (Remote Desktop Protocol) dan VNC (Virtual Network Computing) dengan aplikasi Remote Pesktop Connection
4 ) Pemblokiran situs dilakukan dengan menggunakan aplikasi squid dan data pemblokiran situs dimasukkan dalam daftar nama pada squid sehingga diperlukannya DNS untuk mengenali alamat yang dituju.

5 ) Sistem operasi mikrotik memiliki kinerja paling cepat saat booting dan shutdown dengan waktu 13,5 detik dan 1,2 detik.

6 ) Penggunaan RAM setelah MySQL dan Apache dijalankan pada MailServer sebesar $165 \mathrm{MB}$ lebih kecil dibandingkan dengan WebServer sebesar 239 MB dan AppServer sebesar 236 MB disebabkan perbedaan aplikasi yang berjalan pada masing-masing server.

7 ) Analisis webtester dan performansi server menunjukkan penggunaan RAM tertinggi adalah WebServer dengan $261940 \mathrm{kB}$ dibanding AppServer dengan $242578 \mathrm{kB}$ dan MailServer dengan $199935 \mathrm{kB}$. Penggunaan prosessor tertinggi adalah WebServer dengan 83,3\% dibanding AppServer dengan 82,1\% dan MailServer dengan 82,9\%.

B. Saran

Adapun saran yang dapat diberikan sehubungan dengan pelaksanaan penelitian ini adalah :

1 ) Penelitian lanjutan untuk penambahan metode keamanan yang dapat dikembangkan lagi seperti menangani serangan Ping of death atau DDoS.

2 ) Penelitian lanjutan untuk menanamkan sistem yang sudah ada dengan penambahan kapasitas memori dan prosessor untuk diimplemetasikan.

3 ) Penelitian lanjutan untuk menangani pemblokiran sebuah alamat web yang menggunakan SSL (Secure Socket Layer).

4 ) Penelitian lanjutan untuk mengintegrasikan sistem yang sudah ada dengan terkoneksi pada internet.

\section{DAFTAR PUSTAKA}

[1] Arfiandi, Arief., "Perancangan, Implementsi, dan Analisis Kinerja Virtualisasi Server Menggunakan Proxmox, Vmware ESX, dan Openstack", Jurnal Teknologi, vol. 5 no.2. 2012, 182-191.

[2] Armbrust, M., A. Fox , R. Griffith, A.D. Joseph, R. Katz dan A. Konwinski, 2009, Above the Cloud: A Beekeley View of Cloud Computing, UC Berkeley Reliable Adaptive Distributed Systems Laboratory, pp. 10-12.

[3] Laudon, Kenneth C \& Laudon, Jane P., SISTEM INFORMASI MANAJEMEN, Edisi 10 BUKU 1, Salemba Empat, Jakarta, 2007.

[4] Mahmood, Zaigham., Cloud Computing for Enterprise Architectures, Springer London Dordrecht Heidelberg., New York, 2011.

[5] Pangera, Abas Ali and Ariyus, Dony., Sistem Operasi, ANDI, Yogyakarta, 2005.

[6] Rifludin, Rahmat., Panduan Membangun Jaringan Komputer Untuk Pemula, PT Elex Media Komputindo, Jakarta, 2003.

[7] Solter, Nicholas A. Jelinek, Gerald., and Miner, David., OpenSolaris Bible, Wiley Publishing. Inc, Indiana, 2009.

[8] Srinivasan, S., Coud Computing Basics, Springer Science+Business Media, New York, 2014.

[9] Syafrizal, Melwin., Pengantar Jaringan Komputer, ANDI, Yogyakarta, 2005.

[10]Tittel, Ed., SCHAUM'S OUTLINE: COMPUTER NETWORKING (JARINGAN KOMPUTER), Erlangga, Jakarta, 2002.

[11] Yani, Ahmad., Panduan Membangun Jaringan Komputer, Kawan Pustaka, Jakarta.

[12]W. Kim and S. Korea, "Cloud Computing: Today and Tomorrow," Engineering, vol. 8, no. 1, pp. 65-72, 2009. 